\title{
The hydrogeological mapping of the southwestern part of Serang Regency, Banten, Indonesia
}

\author{
Ahmad Cahyadi ${ }^{1, *}$, Romza Fauzan Agniy², Nurul Khakhim³ ${ }^{3}$ Setyawan Purnama ${ }^{1}$, Igor Yoga Bachtiar ${ }^{4}$, \\ and Wikan Jaya Prihartanto ${ }^{5}$ \\ ${ }^{1}$ Department of Environmental Geography, Faculty of Geography, Universitas Gadjah Mada, Indonesia \\ ${ }^{2}$ Master on Planning and Management of Coastal Area and Watershed, Faculty of Geography, Universitas Gadjah Mada, Indonesia \\ ${ }^{3}$ Department of Geographic Information Science, Faculty of Geography, Universitas Gadjah Mada, Indonesia \\ ${ }^{4}$ The Ministry of Agrarian Affairs and Spatial Planning/National Land Agency, Indonesia \\ ${ }^{5}$ Master Program on Remote Sensing, Faculty of Geography, Universitas Gadjah Mada, Indonesia
}

\begin{abstract}
The development of Serang City as the central government of Banten Province leads to persistently increasing demand for clean water in the area and its surroundings. This study aimed to perform the hydrogeological mapping of the southwestern part of Serang Regency. The study area covered four districts, namely Baros, Padarincang, Paburuan, and Ciomas. These four districts are the clean water source of Serang City that also functions as a buffer zone designed for the development of freshwater fishery and wetland agriculture. Hydrogeological mapping in the study area is expected to be one of the inputs in planning the use of water resources. The method used in this research included analyses of drill data, geophysical measurement results, the findings of previous studies, hydrological map scale 1:250000, and geological map scale 1:100000, as well as geomorphological mapping and field survey. This research produced six classes of hydrogeological units that covered areas with scarce groundwater productivity up to those with high groundwater productivity.
\end{abstract}

\section{Introduction}

Serang City has grown quite rapidly since its establishment as the capital of Banten Province in 2000 [1]. Banten is a new province in Indonesia that was formerly part of West Java Province [2]. Serang City experiences extensive development as an attempt to support its function as the capital of the province [3]. This development leads to the increasing demand for resources to meet the needs of the city, for instance, the water resource needs.

Such development affects not only the environmental conditions of the city but also the surrounding buffer zone. The impact is apparent in the withdrawal of clean water in the southwestern part of the city and the utilization of the space allocated for food provisions (e.g., agriculture and fishery sectors). Studies related to the water resource potential in Serang City thereby have to address this impact to avoid damages to the resources.

This study aimed to map the hydrological nature of the southwestern part of Serang Regency, Banten Province at a scale of 1:50000. This location is the clean water source of Serang City, as well as a buffer zone developed for wetland agriculture and fishery. The study area included four districts, namely Baros, Ciomas, Paburuan, and Padarincang. The requisite for implementing groundwater management is the hydrogeological characteristics of a region [4-7]. These data include aquifer characteristics that are observable from drill data, geophysical measurement results, pumping test data, hydrogeological features (e.g., rock structure, rock type, and the presence of springs, lakes, ponds, and rivers), and underground caves and rivers (i.e., the typical features of areas dominated with dissolution process) [8-10]. Therefore, the availability of hydrological database, which in this case is hydrogeological map, is imperative [11-15]. This map can later be used as the basis for planning a sustainable groundwater resource management in a region.

\section{Methods}

\subsection{Rainfall analysis}

Rainfall is a potential water resource [16]. It is inseparable from the hydrological cycle that places rain as the main recharge of water resource in a region [17]. Regional rainfall can be calculated from the rainfall data recorded in rain gauge stations that are installed within the observed area or outside-with a consideration that they can still represent the rainfall in the region [18]. It can be determined using isohyet. This method relies on interpolation between adjacent rain stations, and the results can represent the distribution of rainfall in the study area.

To calculate the regional rainfall, this study used rainfall data from five stations within and outside the study area. The data range was only five years due to

\footnotetext{
* Corresponding author: ahmadcahyadi@geo.ugm.ac.id
} 
limited data availability. These rainfall data, as presented in Table 1, were obtained from the Meteorological, Climatological, and Geophysical Agency in Serang Regency. The isohyet was developed with interpolation method based on the position of the rainfall station [19]. The interpolation was carried out using the geostatistical tools in ArcGIS 10.2. software ArcGis 10.2.

\subsection{Hydrogeological mapping}

The hydrogeological mapping process in the study area relied on the analyses of drill data, geophysical measurement results, the findings of previous studies, hydrogeological map (scale 1:250000), geological map (scale 1:100000), and the results of geomorphological mapping and field survey. The scale of the hydrogeological map generated from this research is 1:50000. The mapping was conducted using hydrogeomorphological unit approach, which had been applied by many experts [20,21]. The detailed mapping is primarily performed by taking into account the characteristics of landforms, namely morphology, active and passive structure, process, genesis, and age (stadium) [21].

\section{Results and discussions}

\subsection{Regional rainfall condition}

The results of the rainfall data interpolation using Kriging geostatistics are shown in Figure 1. In this study, the data distribution best suits this interpolation method and has a small error value. The isohyet line on the map represents an equal amount of rainfall or, in other words, the area where the line passes through receives the same amount of rain as the value represented by the line. The isohyet map of the study area was developed with an interval of 100-mm rainfall.
The annual rainfall of the study area is in the range of $1,600-2,700 \mathrm{~mm}$. The isohyet map also shows that the western-southwestern areas, i.e., Ciomas and Padarincang District, have relatively high rainfall up to $2,700 \mathrm{~mm}$. The rain shows a decreasing trend to 1,600 $\mathrm{mm}$ towards the eastern-northeastern parts of the study area. The orographic factor of Karang Volcano causes this condition. The slope aspect and the elevation of Ciomas and Padarincang function as a topographic barrier that causes the water vapor from the Java Sea to rise over Karang Volcano and transform into orographic rain on the windward side. High precipitation potentially contributes to substantial groundwater recharge in the study area.

\subsection{Hydrogeological and groundwater potential}

The hydrogeological map of the study area, as presented in Figure 2, provides information on lithological composition, rock permeability, spring distribution, groundwater availability, and aquifer productivity. There are at least four compositions of the surface lithology of the study area, namely young volcanic deposits, alluvium deposits, Tufa Banten, and andesitic lava. The young volcanic deposit is dominant in the study area, and it is distributed from the west to the east. Alluvium deposits are found only in the northwest of the study area, associated with Swamp Lake, a former volcanic crater. Tufa Banten composes the lithology of the northeastern area. An indication of andesitic lava is identified in the southern part of the study area, associated with the presence of Karang Volcano.

Other information provided by the Hydrogeological Map of the Study Area is groundwater availability and aquifer productivity. There are three types of groundwater availability and aquifer productivity (aquifer groups) in the study area. Each of these types is divided further into six classes of hydrogeological unit.

Table 1. Annual rainfall data in 5 rain gauge stations in the study area.

Source: The Meteorological, Climatological, and Geophysical Agency (BMKG) of Serang Regency (2016).

\begin{tabular}{|l|c|c|c|c|c|c|c|c|}
\hline \multirow{2}{*}{ Stations } & \multirow{2}{*}{ Longitude } & \multirow{2}{*}{ Latitude } & \multicolumn{5}{c|}{ Annual rainfall (mm) } & $\begin{array}{c}\text { Annual } \\
\text { average } \\
\text { (mm) }\end{array}$ \\
\cline { 5 - 9 } & & & $\mathbf{2 0 1 1}$ & $\mathbf{2 0 1 2}$ & $\mathbf{2 0 1 3}$ & $\mathbf{2 0 1 4}$ & $\mathbf{2 0 1 5}$ & 1,643 \\
\hline Baros & $106^{\circ} 13^{\prime} 28^{\prime \prime} \mathrm{E}$ & $06^{\circ} 21^{\prime} 55^{\prime \prime} \mathrm{S}$ & 1,403 & 1,376 & 2,301 & 1,897 & 1,237 & 1,643 \\
\hline Ciomas & $106^{\circ} 03^{\prime} 45^{\prime \prime} \mathrm{E}$ & $06^{\circ} 22^{\prime} 83^{\prime \prime} \mathrm{S}$ & 2,210 & 2,400 & 3,672 & 2,827 & 2,514 & 2,725 \\
\hline Pabuaran & $106^{\circ} 07^{\prime} 19^{\prime \prime} \mathrm{E}$ & $06^{\circ} 20^{\prime} 53^{\prime \prime} \mathrm{S}$ & 1,978 & 1,604 & 2,712 & 2,289 & 1,957 & 2,108 \\
\hline Padarincang & $105^{\circ} 93^{\prime} 31^{\prime \prime} \mathrm{E}$ & $06^{\circ} 22^{\prime} 02^{\prime \prime} \mathrm{S}$ & 2,352 & 2,703 & 3,764 & 2,468 & 2,374 & 2,732 \\
\hline Serang & $106^{\circ} 07^{\prime} 91^{\prime \prime} \mathrm{E}$ & $06^{\circ} 06^{\prime} 69^{\prime \prime} \mathrm{S}$ & 1,142 & 1,187 & 2,271 & 1,520 & 1,304 & 1,485 \\
\hline
\end{tabular}

The first type is aquifer with fissure and intergranular flow. Based on the condition, it is divided into three classes, namely productive aquifer with local distribution, medium-productivity aquifer with wide distribution, and high-productivity aquifer with wide distribution. A productive aquifer with local distribution represents aquifer with widely diverse permeability in which usable groundwater cannot be found even by drilling due to the very deep water table. This location is characterized by local springs that can be developed with small discharge. The second condition, i.e., mediumproductivity aquifer with wide distribution, is aquifer with highly various permeability; the unconfined aquifer is mostly deep, and the well's discharge is averagely less than $5 \mathrm{~L} / \mathrm{s}$. Meanwhile, the third condition, i.e., highproductivity aquifer with wide distribution, is aquifer 
with various permeability; the groundwater depth is also diverse, and the well's discharge is commonly less than $5 \mathrm{~L} / \mathrm{s}$. The second type includes aquifer with groundwater flowing through intergranular spaces with medium productivity and wide distribution. It was found in alluvium deposits located in the Swamp Lake in Padarincang District. This condition represents aquifer with medium to low permeability, various groundwater table from the top ground to well below the ground level-as identified in areas with dense industrial buildings, and a well's discharge smaller than $5 \mathrm{~L} / \mathrm{s}$.

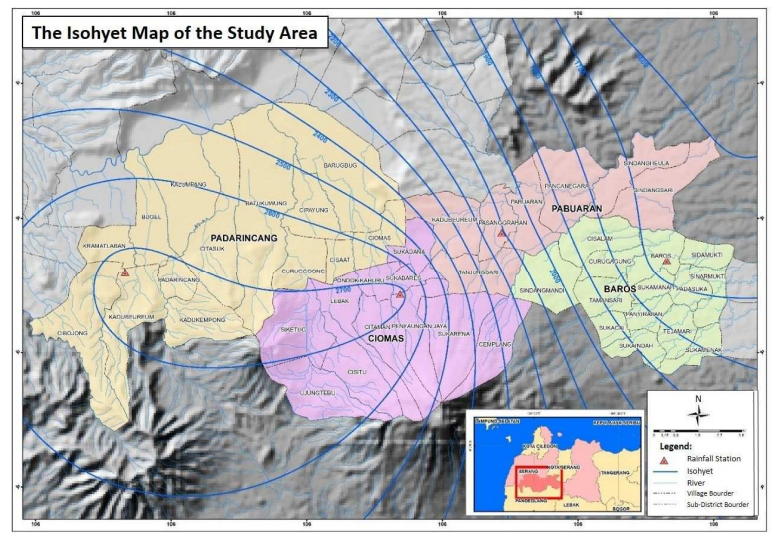

Fig. 1. Spatial distribution of the mean annual rainfall over study area.
The third type represents fissured or porous aquifer with small productivity and areas where groundwater is rare. There are two conditions in this aquifer, namely low-productivity aquifer with local distribution and area with rare groundwater. The low-productivity aquifer is local and shows low to very low permeability. Local groundwater (narrow area and random occurrence) can be obtained in limited quantities primarily in the valley or the weathering zone of massive rock. Areas with rare groundwater on the hydrogeological map represents a condition where groundwater is very difficult to obtain.

The distribution and the extent of the six types of groundwater availability and aquifer productivity (hydrogeological unit) in the study area are presented in Figure 1 and Table 2. The hydrogeological map of the study area (Figure 1) shows the distribution of each groundwater availability and aquifer productivity. The first type, i.e., aquifer with fissure and intergranular flow, along with its three types of condition, is the most widely distributed aquifer in the study area. Table 2 shows the calculation of the extent of each aquifer type based on the groundwater availability and aquifer productivity in the study area. The medium-productivity aquifer with wide distribution and fissure and intergranular flow is the most extensive aquifer as it covers an area of 7,477.07 ha. This table also classifies the aquifer in Padarincang District as the one with the most diverse conditions because it has five (out of six) types of conditions.

Table 2. The extent of each condition of aquifer in the study area

\begin{tabular}{|c|c|c|c|c|c|}
\hline \multirow{2}{*}{ Aquifer's Conditions } & \multicolumn{4}{|c|}{ Area (ha) } & \multirow{2}{*}{$\begin{array}{c}\text { Total area } \\
\text { (ha) }\end{array}$} \\
\hline & Baros & Ciomas & Pabuaran & Padarincang & \\
\hline $\begin{array}{l}\text { Medium-productivity aquifer with wide distribution } \\
\text { and intergranular flow (Aquifer I) }\end{array}$ & 0.00 & 0.00 & 0.00 & $2,382.09$ & $2,382.09$ \\
\hline $\begin{array}{l}\text { Productive aquifer with fissure and intergranular } \\
\text { flow and local distribution (Aquifer II) }\end{array}$ & 959.73 & 2.557 .92 & 745.97 & $2,328.70$ & $6,592.32$ \\
\hline $\begin{array}{l}\text { Medium-productivity aquifer with wide distribution } \\
\text { and fissure and intergranular flow (Aquifer III) }\end{array}$ & $2,803.46$ & 434.99 & $1,784.21$ & $2,454.41$ & $7,477.07$ \\
\hline $\begin{array}{l}\text { High-productivity aquifer with wide distribution and } \\
\text { fissure and intergranular flow (Aquifer IV) }\end{array}$ & 0.00 & 0.00 & 0.00 & $1,205.36$ & $1,205.36$ \\
\hline $\begin{array}{l}\text { Small-productivity aquifer with local distribution } \\
\text { (Aquifer V) }\end{array}$ & 0.00 & 0.00 & $1,296.50$ & 0.00 & $1,296.50$ \\
\hline Area with rare groundwater (Aquifer VI) & 0.00 & $2,511.63$ & 0.00 & $1,542.08$ & $4,053.71$ \\
\hline
\end{tabular}




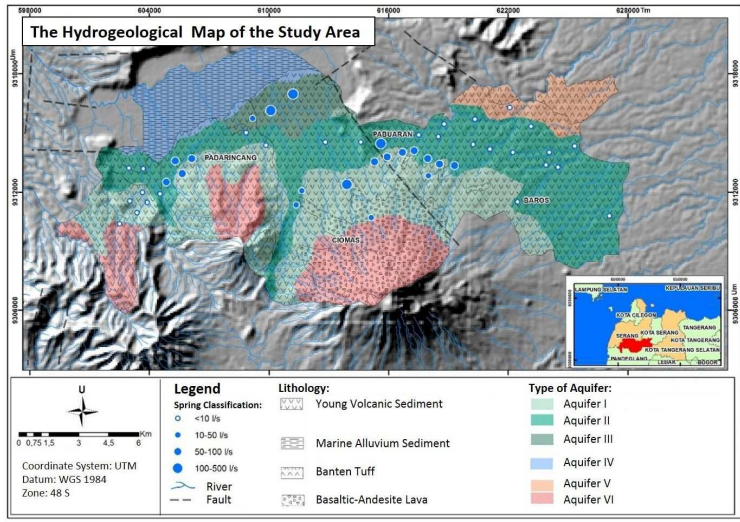

Fig. 2. The hydrogeological map of the study area.

The last information provided by the hydrogeological map of the study area is spring distribution. During the inventory, at least 49 springs were identified. These springs can be grouped by discharge into four classes, as shown in Table 3. Spring with a discharge of less than 10 $\mathrm{L} / \mathrm{s}$ has the largest distribution in the study area (28 springs). Administratively, Padarincang District has the most number of springs (21 springs). The emergence of springs in the study area shows a pattern that follows the break of slope in Karang Volcano. The same case is also found in other areas like Merapi Volcano [22] and Lawu Volcano [23] in Central Java Province. Some springs also appear due to the influence of faults. Nevertheless, the emergence of springs at the break of slope, or the spring belt, is more dominant.

\section{Conclusion}

Annual rainfall in the study area is in the range of 1,600 $2,700 \mathrm{~mm}$, which indicates the potential for substantial groundwater recharge. Based on the analysis results, the condition of aquifer in the study area can be classified into six types, namely (1) medium-productivity aquifer with wide distribution and intergranular flow, (2) productive aquifer with fissure and intergranular flow and local distribution, (3) medium-productivity aquifer with wide distribution and fissure and intergranular flow, (4) high-productivity aquifer with wide distribution and fissure and intergranular flow, (5) small-productivity aquifer with local distribution, and (6) areas with rare groundwater. The field survey identified 49 springs in the study area. These springs were found primarily at the break of slope, forming the spring belt of Karang Volcano.

This research is part of a study entitled "Study of Freshwater Aquaculture Potential in Serang Regency". It was performed with the cooperation of Faculty of Geography, Universitas Gadjah Mada and the Office of Marine, Energy, and Mineral Resource of Serang Regency, Banten Province. Authors would like to thank both parties for the opportunity to be part of the researcher team in the study.

Table 3. The springs in the study area.

\begin{tabular}{|c|c|c|c|c|c|}
\hline \multirow{2}{*}{ Districts } & \multicolumn{4}{|c|}{ Spring classification } & \multirow{2}{*}{ Number of springs } \\
\hline & $<10 \mathrm{~L} / \mathrm{s}$ & $100-500 \mathrm{~L} / \mathrm{s}$ & $10-50 \mathrm{~L} / \mathrm{s}$ & $50-100 \mathrm{~L} / \mathrm{s}$ & \\
\hline Baros & 6 & 0 & 0 & 0 & 6 \\
\hline Ciomas & 0 & 1 & 2 & 1 & 4 \\
\hline Pabuaran & 10 & 1 & 1 & 6 & 18 \\
\hline Padarincang & 12 & 2 & 2 & 5 & 21 \\
\hline Number of springs & 28 & 4 & 5 & 12 & 49 \\
\hline
\end{tabular}

\section{References}

1. A.P. Putra. Analisis Potensi dan Prioritas Pengembangan Pariwisata di Kota Serang Provinsi Banten. Bachelor Thesis. Surakarta, Universitas Muhammadiyah Surakarta (2017)

2. R.S. Wijono. Di Bawah Bayang-bayang Ibukota: Penataan Daerah Provinsi Banten dari Zaman Kolonial sampai Zaman Reformasi. Jurnal Sejarah Citra Lekha, 2(2), 126-142 (2017)

3. Kantor Perwakilan Bank Indonesia Provinsi Banten. Kajian Ekonomi dan Keuangan Regional Provinsi Banten. Research Report. Serang, Bank Indonesia (2017)
4. R.C. Gogu, G. Carabin, V.Hallet, V. Peters, A. Dassargues. GIS-based Hydrogeological Database and Groundwater Modelling. Hydrogeology Journal, 9, 555-569 (2001)

5. J.E. Moore. Field Hydrogeology: A Guide for Site Investigations and Report Preparation. Boca raton, CRC Press (2002)

6. J. Margat, J. van der Gun. Groundwater around the World. Boca Raton, CRC Press (2013)

7. R.T. Ranganai, M.D. Moidaki, J.G. King, Z.B. Bagai. Geophysical and Hydrogeological Groundwater Prospectivity Mapping in the Kraaipan GraniteGreenstone Terrain, Southeast Botswana. Journal of Water Resource and Protection, 9, 1270-1298 (2017) 
8. J. Terzic, F. Sumanovac, R. Buljan. An Assessment of Hydrogeological Parameters on the Karstic Island of Dugi Otok, Croatia. Journal of Hydrology, 343, 2942 (2007)

9. W.D. Weight. Hydrologeology Field Manual, Second Edition. New York, The McGRaw-Hill Companies, Inc. (2008)

10. A. Cahyadi, I.A. Riyanto, N. Listyaningrum, S.F. Lestari. Pembuatan Data Dasar Hidrogeologi Daerah Istimewa Yogyakarta dan Provinsi Jawa Tengah. Research Report. Faculty of Geography, Universitas Gadjah Mada (2017)

11. S.Purnama, E. Febriarta, A. Cahyadi, N. Khakhim, L. Ismangil, H. Prihatno. Analisis Karakteristik Akuifer Berdasarkan Pendugaan Geolistrik di Pesisir Kabupaten Cilacap Jawa Tengah. Jurnal Geografi, 11(22), 155-165 (2013)

12. S.M. Shirazi, Md.I. Adham, N.H. Zardari, Z. Ismail, H.Md. Imran, M.A. Mangrio. Groundwater Quality and Hydrogeological Characteristics of Malaca State in Malaysia. Journal of Water and Land Development, 24, 11-19 (2015)

13. H.I. Chamine, J.M. Carvalho, J. Teixeira, L. Freitas. Role of Hydrogeological Mapping in Groundwater Practice: Back to Basics. European Geologist, 40, 34-42 (2015)

14. S. Suprayogi, S. Purnama, R.F. Agniy, A. Cahyadi. Potensi Airtanah Statis di Daerah Tangkapan Air Goa Pindul Kabupaten Gunungkidul. Proceeding of National Seminar on Environmental Geography I, Faculty of Geography, Universitas Gadjah Mada (2016)

15. Sunarto, A. Cahyadi, M.A. Marfai, S.H. Murti, H. Fatchurohman, M.N. Malawani. Karakteristik Akuifer Wilayah Kepesisiran Parangtritis, Kabupaten Bantul. Proceeding of National Seminar on Geography I, Faculty of Geography, Universitas Gadjah Mada (2017)

16. H. Nurrohmah, A. Cahyadi, Analisis Pemenuhan Kebutuhan Air Domestik dengan Airtanah di Daerah Aliran Sungai Kayangan Kabupaten Kulonprogo. Proceeding of National Seminar on Environmental Geography I, Faculty of Geography, Universitas Gadjah Mada (2016)

17. A. Cahyadi, F.A. Hartoyo. Pemanfaatan Sistem Informasi Geografis (SIG) untuk Pemetaan Imbuhan Airtanah dan Kerentanan Airtanah di Kawasan karst (Studi Kasus di Kecamatan Paliyan dan Kecamatan Saptosari, Kabupaten Gunungkidul). Proceeding of National Seminar on Information Technology Application, Universitas Islam Indonesia (2011)

18. H. Nurrohmah, Sudarmadji, A. Cahyadi. Kajian Kekeringan Meteorologis dan Kaitannya dengan Agihan Mata Air di Kabupaten Kulonprogo, Daerah Istimewa Yogyakarta. Proceeding of National Seminar on Environmental Geography I, Faculty of Geography, Universitas Gadjah Mada (2016)
19. S.H. Lai, M.S.M. Amin, P.L. Law, Y.S. Mah. Applications of GIS and Remote Sensing in the Hydrological Study of the Upper Bernam River Basin, Malaysia. Journal-The Institution of Engineers Malaysia, 69(1), 14-18 (2008)

20. A.G. Brown. 1995. Geomorphology and Groundwater. Chichester, John Wiley and Sons.

21. A. Cahyadi, A. Rofi, R. Harini. Pemetaan Potensi Airtanah di DAS Juwet Kabupaten Gunungkidul. Proceeding of National Seminar on Environmental Geography I, Faculty of Geography, Universitas Gadjah Mada (2016)

22. E. Nurjani, T.N. Adji, K.S. Harjo, A. Cahyadi. Inventarisasi Potensi Sumberdaya Air di Desa Wukirsari, Kecamatan Cangkringan untuk Menentukan Solusi Alternatif Akibat Kerusakan Jaringan Irigasi oleh Banjir Lahar Pasca Erupsi Merapi 2010. Research Report. Vocational College, Universitas Gadjah Mada (2011)

23. L.W. Santosa. Kajian Hidrogeologi Mataair di Sebagian Lereng Barat Gunungapi Lawu. Forum Geografi, 20(1), 68-85 (2006) 